\title{
PREDICTORS OF EATING DISORDER RISK IN ANOREXIA NERVOSA ADOLESCENTS
}

\author{
Maja Batista ${ }^{1}$, Lana Ž igić Antić $^{1}$, Orjena $\check{Z}_{\text {aja }}{ }^{1}$, Trpimir Jakovina ${ }^{2}$ and Ivan Begovac ${ }^{2,3}$ \\ ${ }^{1}$ Department of Pediatrics, Sestre milosrdnice University Hospital Centre, Zagreb, Croatia; \\ ${ }^{2}$ Department of Psychological Medicine, Zagreb University Hospital Centre, Zagreb, Croatia; \\ ${ }^{3}$ School of Medicine, University of Zagreb, Zagreb, Croatia
}

\begin{abstract}
SUMMARY - The purpose of the present study was to examine the association among the risk of eating disorder (ED), psychological adjustment, empathy, attachment style and thin-ideal internalization among adolescents with anorexia nervosa (AN), as compared to a healthy control (HC) group. The Questionnaire of General Data, the Eating Disorders Inventory-3 (EDI-3), the Questionnaire of Sociocultural Attitudes Towards Appearance-3 (SATAQ-3), the Experiences in Close RelationshipsRevised (ECR-R) and the Basic Empathy Scale (BES) were administered to 35 female adolescents with $\mathrm{AN}$ and $35 \mathrm{HC}$ adolescents. Eating disorder risk was found to be highest in $\mathrm{AN}$ females with higher levels of general psychological maladjustment (GPMC), followed by HC females with higher thin-ideal internalization. In the $\mathrm{AN}$ group, attachment style and thin-ideal internalization in combination with GPMC were not indicated as significant predictors of eating disorder risk. Study data provide support to conceptualizations of EDs that emphasize the role of general psychological maladjustment in the development of EDs.
\end{abstract}

Key words: Anorexia nervosa; Adolescent; Emotional adjustment; Feeding and eating disorders; Empathy; Surveys and questionnaires; Croatia

\section{Introduction}

For centuries, there has been great interest in the relation of eating and body weight with emotional and physiological health. Eating disorders (EDs) are related to eating habits and behavior, and have been characterized for developed Western countries ${ }^{1}$. Anorexia nervosa (AN) is one of the main EDs. According to DSM-V classification ${ }^{2}$, AN could be defined as a disorder that mainly occurs in adolescents and young adults, mostly female, characterized by persistent and successful weight loss. AN is characterized by permanently restricted calorie intake, which leads to a significant reduction in body weight, in the context of the minimum expected weight for age, sex, developmental

Correspondence to: Maja Batista, MSc Clin Psychol, Department of Pediatrics, Sestre milosrdnice University Hospital Centre, Vinogradska c. 29, HR-10000 Zagreb, Croatia

E-mail: crnkovic_maja1@yahoo.com

Received February 6, 2017, accepted August 25, 2017 stage and physical health. Moreover, there is intense fear of gaining weight or becoming fat, despite the significantly low weight, distorted perceptions of their weight or body shape, undue influence of body shape and weight on self, or continuing lack of recognizing the seriousness of the current low body weight. The average age at the onset of anorexia is 17 years, with a prevalence of $0.5 \%-1 \%$ in young adult women.

Recent theories have characterized ED as a disorder of multifactorial nature. In order to understand $\mathrm{ED}$, it is necessary to take into account the environmental, social, psychological, biological, and cultural factors. The popularity of TV, movies, and magazines leads to very successful propagation of the ideals of beauty ${ }^{3}$. Wertheim et al. ${ }^{4}$ report that girls having diet is associated with social factors, such as feeling worried, verbal comments given by others, to achieve thinness they believe will appeal to the others, or because their friends are on a diet. Some family and twin studies 
show a strong genetic component in $\mathrm{AN}^{5}$, which is mostly activated in puberty ${ }^{6,7}$, and interacts with the environmental component ${ }^{8}$. Current studies suggest a major role of hormones in increased heritability of ED in puberty, and of the first menstruation at an early age as a risk factor for the development of $\mathrm{ED}^{9,10}$. AN usually occurs in early puberty, although we are witnessing a shift towards younger age groups ${ }^{11}$. Puberty itself is a risk factor for the development of ED, which is considered as an inappropriate response to pubertal events. Pubertal girls are daily imbued with uncertainty about the appearance of their body, comparing it with peer body, and negative perceptions of their body image are very likely decisive for turning to diet, making the risk of developing ED higher ${ }^{12}$. Suddenly changed shape and dimensions of the body have psychological effects, which are reflected primarily as a negative perception of the body and negative self-evaluation. The views are formed in early adolescence in relation to the body, and diet can ultimately favor development of clinical $\mathrm{ED}^{13}$. If we look closer to psychological factors, EDs are connected with higher depressiveness, lower selfesteem, higher body dissatisfaction, perfectionism, and other psychiatric disorders ${ }^{1,14,15}$. As can be seen, a full range of risk factors are associated with the development of AN.

Attachment regulates the conduct of closeness between the child and the parents, and a unique, evolutionary based motivational mechanism, the primary function of which is to provide protection and emotional security ${ }^{16}$. Different forms of early attachment can be considered as strategies designed to solve adaptive problems related to different kinds of environment in which individuals grew up, i.e. our ancestors ${ }^{17}$. Uncertain adherence is associated with the development of anorexia, however, it is not certain that an identifiable group of insecure attachment styles plays a role in developing disorders ${ }^{18,19}$.

Although there has been a growing number of experimental studies on the risk factors for eating pathology and empathy, this literature has not been critically reviewed or synthesized. According to Schipper and Petermann ${ }^{20}$, based on interrelations between emotion processes and social information processing and recent neuroscientific findings showing that empathy deficits might not only result in difficulties labeling others' emotions but one's own emotions too, they suggest that empathy deficits might serve as a potential trigger of emotion dysregulation. Considering the presented information, we assume that a healthy amount of empathy builds the foundation of an effective emotion regulation. Empathy could be defined as the ability of recognizing other's feelings, the cause of these feelings, and to be able to participate in the emotional experience of an individual without becoming part of $\mathrm{it}^{21}$. There are two dimensions of empathy, cognitive and affective empathy. Cognitive empathy implies understanding the others' feelings ${ }^{22}$, whereas affective empathy defines empathy as an observer's emotional response to the affective state of another person ${ }^{23}$. Individuals with AN have impaired cognitive empathy, even the understanding of others' emotions ${ }^{24}$, while personal distress could be a persistent feature of $\mathrm{AN}$ that leads to poor emotional awareness and regulation ${ }^{25}$. For instance, AN has modified emotional facial expression, shows less facial expression, and reports less positive but not less negative emotions than the healthy control $(\mathrm{HC})$ group $^{26}$. Moreover, Davies et al. ${ }^{27}$ found that individuals with AN showed less positive expression, with less negative expression in response to showing a sad clip. These factors could affect effective emotional regulation and social relations ${ }^{28}$. Some studies found no differences between $\mathrm{AN}$ and $\mathrm{HC}$ individuals in their self-reported empathy and systemizing, with AN higher scores on the autism-spectrum quotient related to $\mathrm{HC}^{29}$.

In adolescents and young adult women, differences in the mental image of the body and the cultural ideal are related with body dissatisfaction, tendency to overestimate the size of the body, depressed mood and bulimic behavior ${ }^{1}$. Thin-ideal internalization predicted ED attitudes indirectly via body dissatisfaction, dietary restraint, and depression. It also predicted ED attitudes directly ${ }^{30}$. Stice ${ }^{31}$ showed that thin-ideal internalization as the ideal of beauty and perceived pressure to thinness (by family, friends, partners and media) predicted and increased body dissatisfaction in girls aged 14-17 years. Body dissatisfaction is a significant predictor of the frequency of dieting and negative emotionality. The media are probably the most powerful transmitters of social and cultural ideals of appearance and therefore play an important role in the development of ED ${ }^{1}$. Early adolescence girls that accepted articles and advertisements as important sources of information on the implementation of diet and maintaining a perfect body were more dissatisfied with their 
appearance. Comparison with slender and famous women from the media reinforces negative emotions concerning their weight and body shape, especially if their body image is negative ${ }^{32}$.

However, to the authors' best knowledge, there are no studies examining the association among the risk factors for ED, psychological adjustment, empathy, attachment style and thin-ideal internalization, particularly in clinical samples. Therefore, the purpose of the present study was to examine psychological adjustment, empathy, attachment style and thin-ideal internalization in female adolescents with AN in comparison to the HC group. Both patient specific psychological constructs and sociocultural attitudes, as well as psychological adjustment profile were described in the study. The primary hypotheses of the study were that adolescents with AN would show 1) a statistically significant higher general psychological maladjustment than the HC group; and 2) a statistically significant impairment in empathy, attachment style and thinideal internalization than the $\mathrm{HC}$ group.

In addition, the goal of the study was to investigate the role of general psychological maladjustment, empathy, attachment style and thin-ideal internalization for the eating disorder risk (EDR). We hypothesized that general psychological maladjustment, insecure or avoidant attachment, thin-ideal internalization, and lower or higher levels of empathy would lead to higher EDR. In this research, we were interested in the predictors of developing EDR in both females with anorexia and $\mathrm{HC}$ group.

\section{Materials and Methods}

\section{Recruitment}

A total of 70 female participants, equally distributed between the AN group $(\mathrm{N}=35)$ and $\mathrm{HC}$ group $(\mathrm{N}=35)$ were included in the study. Diagnosis was established by medical doctors (psychiatrists). Recruitment of patients took place at two participating centers. One centre was a specialized pediatric hospital unit for inpatients and outpatients with an ED: Gastroenterology Unit, Department of Pediatrics, Sestre milosrdnice University Hospital Centre, Zagreb, Croatia and Department of Psychological Medicine, Zagreb University Hospital Centre, Zagreb, Croatia. Recruitment of patients was carried out from January 2014 to January 2015 .
Patients were diagnosed by a psychiatrist using the Diagnostic and Statistical Manual of Mental Disorders (DSM), $4^{\text {th }}$ edition ${ }^{33}$. Subsequently, the patients were re-diagnosed in accordance with the DSM, $5^{\text {th }}$ edition ${ }^{2}$. A total of 35 patients met the DSM-5 diagnostic criteria for AN. The study included only inpatient adolescent females with AN, with no other psychiatric disorders as comorbidity. All participants had suffered from anorexia for at least one year before setting the diagnosis. Inclusion criteria were age 11-19 years, with body mass index percentile for age $<5 \%$ and body mass index (BMI) $<18.5$ at the time of hospital admission. In order to avoid the impact of malnutrition on the research results, all patients were administered questionnaires after one-month stay in the inpatient unit. Therefore, in some patients BMI percentile for age was greater than 5\% and BMI was higher than 18.5 at the time of completing the questionnaire (Table 1). A gastroenterologist estimated medical stability of all participants in the experimental group according to the guidelines set by the Society for Adolescent Medicine ${ }^{34}$, and directed by the Workgroup for Classification of Eating Disorders in Children and Adolescents $^{35}$. Excluded were inpatients that were, according to the gastroenterologist examination, severely malnourished and in deep somatic mortal danger, or patients with severe bradycardia, hypotension, hypothermia, and orthostatic changes in heart rate or blood pressure.

The HC female group $(\mathrm{N}=35)$ was recruited from elementary and secondary schools in Zagreb (both vocational and humanistic). Females of the relevant age range were invited to participate. Patients and $\mathrm{HCs}$ were matched $1: 1$ by age, type of school (i.e. within one grade), and matched at the group level for the socio-demographic background.

\section{Ethical aspects and procedure}

Participation was voluntary; patients and their parents were informed that nonparticipation would not affect their treatment. Written and verbal information about the study was provided before recruitment. A written informed consent was obtained from the holder of custody, and it was a guarantee of data anonymity and confidentiality. The study design was cross-sectional, in one period of data import. The study was conducted by a clinical psychologist, $\mathrm{PhD}$ student who was with the participants throughout the time of fill- 
Table 1. Demographic data of the sample $(N=70)$

\begin{tabular}{|l|l|l|l|l|l|l|}
\hline \multirow{2}{*}{} & \multicolumn{2}{|c|}{ M (SD) } & \multicolumn{2}{|c|}{ TR } & N & N \\
\cline { 2 - 7 } & AN & HC & AN & HC & AN & HC \\
\hline Age (years) & $15.17(1.52)$ & $15.14(1.44)$ & $12.0-18.0$ & $13.0-18.0$ & 35 & 35 \\
Body mass index & $16.00(2.82)$ & $20.05(2.23)$ & $10.9-23.1$ & $15.4-25.7$ & 35 & 35 \\
$\begin{array}{l}\text { Z-scontile } \\
\text { Lowest weight ever in adolescence }\end{array}$ & $12.06(19.01)$ & $45.28(21.59)$ & $0.0-71.8$ & $87.5-45.28$ & 35 & 35 \\
Deliberately lost kilograms ever & $-2.55(2.35)$ & $-0.16(.68)$ & $-9.71-0.58$ & $-2.12-1.15$ & 35 & 35 \\
& $14.27(7.17)$ & & $29.0-57.0$ & & 35 & 35 \\
& Frequency & & $5.0-30.0$ & & 35 & 35 \\
\hline $\begin{array}{l}\text { Education level: } \\
\text { elementary school }\end{array}$ & AN & HC & AN & HC & AN & HC \\
$\begin{array}{l}\text { high school } \\
\text { technical school }\end{array}$ & 11 & 10 & 31.4 & 29.4 & & \\
\hline $\begin{array}{l}\text { Financial status: } \\
\text { low } \\
\text { below average }\end{array}$ & 7 & 7 & 20 & 20.6 & 35 & 34 \\
$\begin{array}{l}\text { average } \\
\text { above average } \\
\text { high }\end{array}$ & 17 & 17 & 48.6 & 48.6 & & \\
\hline
\end{tabular}

$\mathrm{M}=$ mean; $\mathrm{SD}=$ standard deviation; $\mathrm{TR}=$ total range; $\mathrm{AN}=$ anorexia nervosa $\mathrm{HC}=$ health control; $\mathrm{N}=$ number of participants

ing out the questionnaires. The study was approved by the local Research Ethics Committee of the participating hospitals and schools, and by the Research Ethics Committee of the School of Medicine, University of Zagreb, as the research was part of a doctoral study.

To achieve high reliability, joint personnel training and supervision were provided continuously during the study period. Highly trained staff managed all assessment tools. Somatic assessment was conducted by one medical doctor. Ongoing rating and supervision were provided by one $\mathrm{PhD}$ student psychologist.

\section{Instruments}

All participants in the AN group filled out the following test battery:

Questionnaire of General and Health Information apposite questionnaire designed for this research that examines general and health information about participants (age, level of education, socioeconomic status of the family, parental marital status, family history of eating disorders, family history of other psychiatric illness, family structure, and data that include physical state: menstrual status, duration of disease prior to testing, etc.). Clinical psychologist also filled out this questionnaire to ensure the reliability of data. Clinical psychologist completed the questionnaire obtaining information from medical records, as well as from participant parents.

\section{Eating Disorder Inventory-3 (EDI-3)}

The EDI-3 is a 91-item self-report questionnaire of psychological traits clinically relevant in individuals with an ED. Participants respond on a 6-point Likert scale ('Always' through 'Never'). It consists of 12 subscales: Drive for Thinness (DT), Bulimia (B), Body Dissatisfaction (BD), Low Self-Esteem (LSE), Personal Alienation (PA), Interpersonal Insecurity (II), Interpersonal Alienation (IA), Interceptive Deficits (ID), Emotional Dysregulation (ED), Perfectionism (P), Asceticism (A) and Maturity Fears (MF). The sum of the subscales comprises 6 composites: Eating Disorder Risk (EDRC), Ineffectiveness (IC), Interpersonal Problems (IPC), Affective Problems (APC), Overcontrol (OC), and General Psychological Maladjustment Composite (GPMC). In the present study, Cronbach's $\alpha$ for GPMC score was 0.96 and 
for EDRC score 0.95 , which is good internal reliability.

\section{Experience in Close Relationship-Revised (ECR-R)}

The ECR-R assesses attachment anxiety (e.g., strong need for care and attention from attachment figures combined with uncertainty about the willingness or capability of attachment figures to respond to $\mathrm{him} / \mathrm{her}$ in an appropriate fashion) ${ }^{36}$ and avoidance dimension (e.g., discomfort with intimacy and need for independence, even in close relationships $)^{36}$. It is a 36-item questionnaire where participants are asked to rate statements based on how they generally feel in emotionally close family relationship ${ }^{37}$. The seven categories range from 'strongly disagree' to 'strongly agree'. Fraley et al. ${ }^{38}$ have presented considerable evidence that the four-category model of attachment is best characterized by the two-dimensional system. Secure adolescents are low in both attachment anxiety and attachment avoidance. Preoccupied adolescents are high in attachment anxiety and low in attachment avoidance. Dismissive adolescents are high in attachment avoidance and low in attachment anxiety. Fearful adolescents are high on both dimensions. Internal consistency for the ECR-R total score was excellent in the current study (Cronbach's $\alpha=0.96$ ).

\section{Basic Empathy Scale (BES)}

The BES was originally developed by Jolliffe and Farrington $^{39}$. The BES has 20 items, nine of which measure cognitive empathy and 11 measure affective empathy on a five-point Likert type scale (1=strongly disagree to $5=$ strongly agree). Before analyses, seven of the items were reverse coded. Therefore, higher scores indicated a higher level of empathy. Jolliffe and Farrington $^{39}$ found a two-factor solution: affective ('My friend's emotions don't affect me much') and cognitive empathy ('I can understand my friend's happiness when she/he does well at something'), and Cronbach's alpha coefficients were 0.85 for the affective component and 0.79 for the cognitive component. Internal consistency for the ECR-R total score was very good in the current study (Cronbach's $\alpha=0.83$ ).

\section{Sociocultural Attitudes Towards Appearance Questionnaire-3 (SATAQ-3)}

The SATAQ-3 is a 30 -item scale measuring the multidimensional impact of socio-cultural influences on body image along four dimensions (Information, Pressure, Internalization-General, and Internalization-Athlete). The four factors are internally reliable, with Cronbach's alpha coefficients generally exceeding $0.80^{40}$. Items were rated on a 5 -point Likert-type scale ( 1 =definitely disagree to $5=$ definitely agree), and subscale scores were computed by taking the mean of items associated with each factor. Correlational, structural equation modeling and prospective studies of the SATAQ-3 have shown consistent and significant associations with measures of body image disturbance and eating pathology ${ }^{41}$. In the present study, Cronbach's $\alpha$ for total score was 0.95 .

\section{Assessment of healthy control subjects}

The HC group subjects were screened for indication of psychiatric disorder during recruitment using the Strengths and Difficulties Questionnaire ${ }^{42}$.

The Strengths and Difficulties Questionnaire (SDQ) is a brief behavioral screening questionnaire for individuals aged 4-17 years. It exists in several versions to meet the needs of researchers, clinicians and educationalists. The SDQ is a 25 -item scale divided into 5 subscales: Emotional Symptoms, Conduct Problems, Hyperactivity, Peer Relationship Problem, Prosocial Behavior, and Total Score. Findings support the use of the SDQ as a genuinely dimensional measure of the child mental health ${ }^{43}$. Furthermore, an identical test battery was administered as in the experimental (AN) group.

\section{Statistical analyses}

Pearson's correlation analysis was performed to investigate the relationship between $\mathrm{ED}$ risk composite and psychological variables. In addition, t-test was used to investigate differences between independent samples. Hierarchical multiple regression analyses were performed to identify predictors of EDRC. If data did not fulfill the requirement of normality, the non-parametric equivalent Wilcoxon Mann-Whitney test was performed. Effect sizes were calculated, taking into account the dependence structure of data by adjusting for correlation within matched pairs $^{44}$. The level of statistical significance was set at $p<0.05$. The Statistical Package for the Social Sciences, version 19.0 (SPSS Inc., Chicago, IL, USA) was used on all data analyses. 


\section{Results}

\section{Sociodemographic and somatic characteristics}

As shown in Table 1 , the mean age in the AN group was 15.1 years $(\mathrm{SD}=1.5)$, range $12-18$ years. The patients in the study cohort were seriously ill, with the mean BMI $16(\mathrm{SD}=2.8)$ and $\mathrm{BMI}$ percentile for age $12.0(\mathrm{SD}=19.0)$. The range for BMI was 10.9-23.1, and for BMI percentile for age 0-71.8 with $\mathrm{z}$-score -2.55 . In order to avoid the impact of malnutrition, patients filled out a battery of questionnaires after one-month stay in inpatient unit, having gained weight during that time. The lowest weight recorded in adolescence was $41.2 \mathrm{~kg}(\mathrm{SD}=7.1)$, range $29-57 \mathrm{~kg}$. Deliberately lost weight amounted to $14.2 \mathrm{~kg}$ $(\mathrm{SD}=6.7)$, range $5-30 \mathrm{~kg}$.

Thirty-two patients had AN restricting type, whereas three patients had AN binge-eating/purging type. Four patients had a family history of ED. The mean duration of disease measured by self-reported duration of changes in eating behavior was 1 year, range 0.6 -more than 2 years. In the experimental (AN) group, almost $65 \%$ of subjects had amenorrhea and in $70 \%$ of them, this was their first inpatient hospital stay. Their parents were mostly married, but in
$20 \%$ of patients their parents were divorced or in the process of getting divorce. In the HC group, $82 \%$ of parents were married. About $97 \%$ of subjects had no history of ED in family, while almost $3 \%$ of girls were malnourished.

\section{Difference between $A N$ and $H C$ groups regarding psychosocial measures}

To determine whether there was a difference between $\mathrm{AN}$ and $\mathrm{HC}$ groups in psychological maladjustment $\mathrm{t}$-test was employed. AN females were found to have significantly higher GPMC scores as compared with HC group ( $t=5.03, p=0.00)$ (Table 2). As expected, a statistically significant difference was confirmed between the AN and $\mathrm{HC}$ groups regarding all specific psychological composites measured in EDI-3: Ineffectiveness $(\mathrm{t}=4.80, \mathrm{p}=0.00)$, Interpersonal Problems $(\mathrm{t}=3.09, \mathrm{p}=0.00)$, Affective Problems $(\mathrm{t}=4.18, \mathrm{p}=0.00)$ and Overcontrol $(\mathrm{t}=4.64, \mathrm{p}=0.00)$, with higher scores in adolescent females with anorexia. If considered more closely, AN females compared to HC group had significantly increased scores in all Eating Disorder Risk and Psychological scales on EDI-3 except for Maturity Fears and Bulimia scales, then in Drive for Thinness ( $\mathrm{t}=5.51, \mathrm{p}=0.00)$, Body Dissatisfaction

Table 2. T-test results in anorexia nervosa $(A N)$ and healthy control (HC) groups

\begin{tabular}{|c|c|c|c|c|c|c|c|}
\hline & Group & $\mathrm{N}$ & $M$ & SD & $\mathrm{T}$ & $\mathrm{df}$ & $\mathrm{p}$ \\
\hline GPMC & $\begin{array}{l}\text { AN } \\
\text { HC }\end{array}$ & $\begin{array}{l}35 \\
35 \\
\end{array}$ & \begin{tabular}{|l|}
436.37 \\
371.83 \\
\end{tabular} & $\begin{array}{l}70.33 \\
28.51 \\
\end{array}$ & 5.03 & 68 & 0.00 \\
\hline SATAQ & $\begin{array}{l}\text { AN } \\
\text { HC }\end{array}$ & $\begin{array}{l}35 \\
35 \\
\end{array}$ & $\begin{array}{l}81.49 \\
73.83 \\
\end{array}$ & $\begin{array}{l}28.96 \\
20.07\end{array}$ & 1.29 & 68 & 0.20 \\
\hline BES & $\begin{array}{l}\text { AN } \\
\text { HC }\end{array}$ & $\begin{array}{l}35 \\
35 \\
\end{array}$ & $\begin{array}{l}76.94 \\
79.80 \\
\end{array}$ & \begin{tabular}{|l|}
9.66 \\
9.17 \\
\end{tabular} & -1.27 & 68 & 0.21 \\
\hline ECR-R & $\begin{array}{l}\text { AN } \\
\text { HC }\end{array}$ & $\begin{array}{l}34 \\
35 \\
\end{array}$ & $\begin{array}{l}110.50 \\
88.46\end{array}$ & $\begin{array}{l}46.70 \\
30.54 \\
\end{array}$ & 2.33 & 67 & 0.02 \\
\hline IC & $\begin{array}{l}\text { AN } \\
\text { HC }\end{array}$ & $\begin{array}{l}35 \\
35 \\
\end{array}$ & $\begin{array}{l}90.63 \\
73.31\end{array}$ & $\begin{array}{l}20.14 \\
7.12\end{array}$ & 4.80 & 68 & 0.00 \\
\hline IPC & $\begin{array}{l}\text { AN } \\
\text { HC }\end{array}$ & $\begin{array}{l}35 \\
35 \\
\end{array}$ & $\begin{array}{l}98.14 \\
85.60\end{array}$ & $\begin{array}{l}18.99 \\
14.66\end{array}$ & 3.09 & 68 & 0.00 \\
\hline APC & $\begin{array}{l}\text { AN } \\
\text { HC }\end{array}$ & $\begin{array}{l}35 \\
35 \\
\end{array}$ & \begin{tabular}{|l|}
97.11 \\
80.83 \\
\end{tabular} & $\begin{array}{l}21.28 \\
8.85\end{array}$ & 4.18 & 68 & 0.00 \\
\hline $\mathrm{OC}$ & $\begin{array}{l}\text { AN } \\
\text { HC }\end{array}$ & $\begin{array}{l}35 \\
35 \\
\end{array}$ & \begin{tabular}{|l|}
93.37 \\
78.31
\end{tabular} & $\begin{array}{l}16.47 \\
9.85\end{array}$ & 4.64 & 68 & 0.00 \\
\hline
\end{tabular}

$\mathrm{N}=$ total number of cases; $\mathrm{M}=$ mean; $\mathrm{SD}=$ standard deviation; $\mathrm{T}$ = $\mathrm{t}$-test value; $\mathrm{df}$ = degree of freedom; $\mathrm{p}=$ level of significance; GPMC = global psychological maladjustment; SATAQ = Sociocultural Attitudes Towards Appearance Questionnaire; BES = Basic Empathy Scale; ECR-R = Experience in Close Relationship-Revised; IC = ineffectiveness; IPC = interpersonal problems; APC = affective problems; $\mathrm{OC}=$ overcontrol 
$(\mathrm{t}=5.23, \mathrm{p}=0.00)$, and in almost all psychological scales (Low Self-Esteem ( $t=4.53, \mathrm{p}=0.00)$, Personal Alienation $(\mathrm{t}=4.64, \mathrm{p}=0.00)$, Interpersonal Insecurity $(\mathrm{t}=2.64, \mathrm{p}=0.01)$, Interpersonal Alienation $(\mathrm{t}=3.04$, $\mathrm{p}=0.00)$, Interoceptive Deficits $(\mathrm{t}=4.65, \mathrm{p}=0.00)$, Emotional Dysregulation ( $\mathrm{t}=2.92, \mathrm{p}=0.00)$, Perfectionism ( $\mathrm{t}=3.03, \mathrm{p}=0.00)$ and Asceticism ( $\mathrm{t}=4.58$, $\mathrm{p}=0.00$ ). No difference between the $\mathrm{AN}$ and $\mathrm{HC}$ groups was recorded in Maturity Fears and Bulimia scales.

A highly significant between-group difference was found in the Experience in Close Relationships (ECR$\mathrm{R})(\mathrm{t}=2.33, \mathrm{p}=0.02)$, with higher scores in AN group. However, there was no between-group difference regarding empathy (BES) and thin-ideal internalization (SATAQ) (Table 2).

\section{Relationship between Eating Disorder Risk Composite (EDRC) and psychosocial measures}

Exploration of relationships between the Eating Disorder Risk Composite (EDRC) and psychosocial variables revealed that $\mathrm{EDRC}$ was related to the GPMC $(\mathrm{r}=0.65, \mathrm{p}<0.01)$, thin-ideal internalization (SATAQ) $(\mathrm{r}=0.39, \mathrm{p}<0.05)$ and Experience in Close Relationships (ECR-R) $(\mathrm{r}=0.47, \mathrm{p}<0.01)$ in AN group. Similar results were recorded for relationships between $\mathrm{EDRC}$ and psychosocial variables in $\mathrm{HC}$ group: EDRC was related to the GPMC $(r=0.44, p<0.01)$, SATAQ $(r=0.59, \mathrm{p}<0.01)$ and ECR-R $(\mathrm{r}=0.43$, $\mathrm{p}<0.01)$. However, empathy (BES) was not related to EDRC in either group (Table 3), so it was excluded from further analysis.

In order to establish predictors of the risk of eating disorders (EDRC), hierarchical multiple regression was performed, with EDRC as a dependent variable (Table 4). According to literature and correlation analysis, the GPMC as a psychological variable was controlled in the first step. In the second step, the ECR-R as a psychosocial measure was entered. Finally, in the third step, the SATAQ as a social measure for thin-ideal internalization was entered. To ensure the validity of the results in hierarchical analysis, we alternated the order of inputting the variables in the analysis, but each time we received identical results. Identical steps were performed separately for the AN and $\mathrm{HC}$ groups. The final model explained $43 \%$ of variance of the risk of ED in the AN group, followed by explanation of $50 \%$ of variance in the HC group.
Table 3. Correlations between EDRC and psychological variables ( $A N$ above diagonal, $H C$ below diagonal)

\begin{tabular}{|l|l|l|l|l|l|}
\hline & GPMC & BES & SATAQ & ECR-R & EDRC \\
\hline GPMC & - & 0.09 & $0.57^{* *}$ & $0.69^{* *}$ & $0.65^{* *}$ \\
BES & -0.21 & - & -0.09 & $0.24^{* *}$ & 0.24 \\
SATAQ & 0.17 & -0.11 & - & $0.56^{* *}$ & $0.39^{*}$ \\
ECR-R & $0.47^{* *}$ & -0.27 & 0.19 & - & $0.47^{* *}$ \\
EDRC & $0.44^{* *}$ & -0.07 & $0.59^{* *}$ & $0.43^{* *}$ & - \\
\hline
\end{tabular}

${ }^{*} \mathrm{p}<0.05 ;{ }^{* *} \mathrm{p}<0.01 ; \mathrm{AN}=$ anorexia nervosa group; $\mathrm{HC}=$ healthy control group; GPMC = Global Psychological Maladjustment Composite; SATAQ = Sociocultural Attitudes Towards Appearance Questionnaire; BES = Basic Empathy Scale; ECR-R = Experience in Close Relationship-Revised; EDRC = Eating Disorder Risk Composite

Table 4. Hierarchical regression analysis showing predictors of eating disorder risk

\begin{tabular}{|l|l|l|l|l|}
\hline & \multicolumn{2}{l|}{ AN } & \multicolumn{1}{l|}{$\mathrm{HC}$} \\
\hline Predictor & $\Delta \mathrm{R}^{2}$ & $\beta$ & $\Delta \mathrm{R}^{2}$ & $\beta$ \\
\hline Step 1 & $0.43^{* *}$ & & $0.19^{* *}$ & \\
GPMC & & $0.65^{* *}$ & & $0.44^{* *}$ \\
\hline Step 2 & 0.00 & & 0.07 & \\
GPMC & & $0.62^{* *}$ & & 0.30 \\
ECR-R & & 0.04 & & 0.29 \\
\hline Step 3 & 0.00 & & $0.24^{* *}$ & \\
GPMC & & $0.61^{* *}$ & & 0.25 \\
ECR-R & & 0.04 & & 0.22 \\
SATAQ & & 0.03 & & $0.50^{* *}$ \\
\hline Total R & $0.43^{* *}$ & & $0.50^{* *}$ & \\
\hline
\end{tabular}

${ }^{*} \mathrm{p}<0.05 ;{ }^{*} \mathrm{p}<0.01 ; \mathrm{AN}=$ anorexia nervosa group; $\mathrm{HC}=$ healthy control group; GPMC = Global Psychological Maladjustment Composite; SATAQ $=$ Sociocultural Attitudes Towards Appearance Questionnaire; ECR-R = Experience in Close RelationshipRevised; EDRC = Eating Disorder Risk Composite; $\Delta \mathrm{R}^{2}=$ the adjusted coefficient of determination; $\beta=$ standardized beta coefficient

The ECR-R and SATAQ did not contribute significantly to the explanation of variance in AN group, whereas the GPMC and ECR-R did not contribute significantly to the explanation of variance in $\mathrm{HC}$ group.

Significant predictors of eating disorder risk was GPMC $(\beta=0.61, p<0.01)$ in AN group and SATAQ $(\beta=0.50, p<0.01)$ in $\mathrm{HC}$ group. Eating disorder risk was found to be highest in more general psychological maladjusted females with AN, followed by $\mathrm{HC}$ females with higher thin-ideal internalization. 


\section{Discussion}

One aim of the study was to describe the general psychological adjustment profile in patients with AN. This was carried out through comparison with the psychological adjustment profile of the HC group. It was expected that patients with $\mathrm{AN}$ would have higher GPMC and its composites than the HC group. Significant between-group difference in GPMC was found. AN females showed a significantly higher levels of GPMC and its specific psychological composites.

The results suggested that adolescents with $\mathrm{AN}$ as compared to HC group had a higher rate of psychological maladjustment, i.e. more interpersonal and affective problems; they appeared to pursuit perfection through self-denial and suffering, and had low self-evaluation and sense of emotional emptiness. In more detail, they had lower self-esteem, wanted to be thinner, were more dissatisfied with their body, were insecure in interpersonal relationships, and had higher emotional dysregulation, asceticism and perfectionism than the $\mathrm{HC}$ group. There was no difference between the AN and $\mathrm{HC}$ groups regarding Maturity Fears and Bulimia. These findings are consistent with the results of several other studies. According to the literature, EDs are marked with psychosocial impairment and comorbid psychopathology $y^{45,46}$. The self-esteem of a female before puberty and in adolescence is an important factor in their predisposition for the development of $\mathrm{ED}^{47}$. Low self-esteem is also associated with ED and with eating attitudes in non-clinical student groups ${ }^{48}$, as well as with anorectic behavior ${ }^{49}$. Halmi et al. ${ }^{50}$ report on the presence of depression during lifespan in 68\% of anorexic females, whereas in control population, the incidence was $21 \%$. Body concerns and diet attempts in adolescents are risk factors for the later development of EDs ${ }^{51,52}$ and always are, at the subclinical level, linked to depression, low self-esteem and anxiety ${ }^{53}$.

The results indicated a highly significant difference between the groups in the ECR-R, demonstrating higher levels of avoidance and anxiety in AN group. Also, significant relationship was found between EDRC and ECR-R in both AN and HC groups. Similar findings were also found in many other studies $^{54-56}$, indicating a significant correlation between anorexia and rejected or preoccupied attachment style.

According to the literature, empathy deficits in terms of low empathic abilities might trigger emotion dysregulation; also too high amount of empathy is a potential trigger of emotion dysregulation. However, in our study the difference was not found between AN and $\mathrm{HC}$ group regarding empathy (BES). In addition, there was no significant correlation between EDRC and empathy in AN and $\mathrm{HC}$ groups. Similar findings found Harrison et al..$^{57}$, where they stated that there was a small difference between the ED and $\mathrm{HC}$ groups for the emotion recognition task (small-medium effect), particularly in the restricting AN group.

Beside ECR-R, significant relationship was found between EDRC and SATAQ, and between EDRC and GPMC in both groups. However, in AN group, significant predictor was only GPMC. On the other hand, in HC group, proven significant predictor of EDRC is only SATAQ. Interestingly, in our study SATAQ was not as significant predictor in AN group, but only in the $\mathrm{HC}$ group. These results are partly in line with our expectations. According to literature, and to the socio-cultural theories that explain the risk of developing ED, SATAQ is a significant predictor for the development of ED. Numerous studies conducted in the last twenty years documented the rise of social desirability of slim female figures ${ }^{3,58,59}$. Research based on the effect of the media indicates that higher exposure to media leads to thinness associated with more pronounced symptoms of $\mathrm{ED}^{60,61}$. One measure of risk that has received a great deal of attention is internalization of the thin ideal ${ }^{62}$. Recent work in the preventive area has demonstrated that internalization may be a causal risk factor for the onset of eating and shape-related disturbances ${ }^{63}$ and a significant predictor of treatment success among adolescent girls and women with $\mathrm{AN}^{64}$. Importantly, it is possible to modify such internalization and changes in this risk factor appear to be related to changes in levels of body dissatisfaction ${ }^{65}$. Data reported by Garner et al. ${ }^{66}$ suggest that both pressures to be slim and achievement expectations are risk factors in the development of AN. Thin-ideal internalization is a causal risk factor for body dissatisfaction, dieting, negative affect, and bulimic pathology, as well as a maintenance factor for bulimic pathology ${ }^{67,68}$. However, these conclusions should be interpreted with caution because most of the studies were from one research group, mostly on nonclinical samples and on bulimia groups, rather than on anorexia sample. It is important to stress that these studies cannot explain why only some adolescents 
who are exposed to cultural messages become concerned about the body and slimming diet. It seems that in our healthy sample the best predictor for the risk of eating disorders is SATAQ, while in the AN group a significant predictor is only GPMC.

Based on these results it can be concluded that the role of psychological maladjustment should not be ignored when it comes to risk of developing ED in adolescence, as the role of sociocultural attitudes about body image in the healthy population should not be neglected, especially in creating prevention programs for ED.

Finally, it is useful to mention some limitations of the study. It should be noted that all the conclusions of this study were in only correlation nature, and do not reflect the causal relationships among the analyzed phenomena. Therefore, the future research should focus on other research approaches, such as cross-sequential draft with the longitudinal component, which would provide more valid information about the direction of impact. Furthermore, the study was conducted on a convenient sample and, as such, must to some extent limits the possibility of generalization of the results to the entire population of adolescents with AN. This study provides a unique contribution to the etiological factors of ED. The results of this study can be useful guidelines for further research in this area. The data provide support for conceptualizations of EDs that emphasize the role of general psychological maladjustment in the development and maintenance of EDs. Further research will concentrate on exploring whether these findings are state or trait features of EDs.

\section{Conclusion}

Clinicians and researchers are unanimous in concluding that in adolescent females with ED they may perceive a specific form of emotional instability. These data confirm that females with AN exhibit different psychological profile than HCs. They are more psychologically maladjusted females with more interpersonal and affective problems, they pursuit the perfection through self-denial and suffering, and they have lower self-evaluation and the sense of emotional emptiness compared to $\mathrm{HC}$ group. It seems that there are no differences between healthy females and females with anorexia regarding empathy, and no association was found between the risk of developing eating disor- der and empathy. The risk of developing eating disorders significantly correlated with thin-ideal internalization, attachment style and global psychological maladjustment. Eating disorder risk was found to be highest in more general psychological maladjusted females with $\mathrm{AN}$, followed by $\mathrm{HC}$ females with higher thin-ideal internalization. Attachment style and thinideal internalization were not proved as significant predictors, in combination with global psychological maladjustment in the $\mathrm{AN}$ female adolescent group.

\section{Acknowledgments}

We would like to thank medical team of the Gastroenterology Unit, Department of Pediatrics, Sestre milosrdnice University Hospital Centre, Zagreb, and medical team of the Department of Psychological Medicine, Zagreb University Hospital Centre, Zagreb. We would also like to thank Vlatka Baretić, psychologist at Lucijan Vranjanin High School in Zagreb, Maja Kralj Stančec, educator at Tourism High School in Zagreb, and Jagoda Siladi, educator at Ksaver Šandor Gjalski Elementary School, Zagreb, Croatia. Special thanks go to all the participants and their parents having participated in the study.

\section{References}

1. Ambrosi-Randić N. Razvoj poremećaja hranjenja. Jastrebarsko: Naklada Slap; 2004. (in Croatian)

2. American Psychiatric Association. Diagnostic and Statistical Manual of Mental Disorders, $5^{\text {th }}$ edn. Washington DC: American Psychiatric Association; 2013.

3. Silverstein B, Peterson B, Perdue L. Some correlates of the thin standard of bodily attractiveness for women. Int J Eat Disord. 1986;5:895-905. doi: 10.1002/1098-108X(198607)5:5<895:: AID-EAT2260050510>3.0.CO;2-W

4. Wertheim EH, Paxton SJ, Schutz HK, Muir SL. Why do adolescent girls watch their weight? J Psychosom Res. 1997;42:345-55. doi: http://dx.doi.org/10.1016/S0022-3999(96)00368-6

5. Bulik CM. (2005). Exploring the gene-environment nexus in eating disorders. J Psychiatry Neurosci. 2005;30:335-9.

6. Klump KL, Gobrogge KL, Perkins PS, Thorne D, Sisk CL, Breedlove SM. Preliminary evidence that gonadal hormones organize and activate disordered eating. Psychol Med. 2006; 36:539-46. doi: https://doi.org/10.1017/S0033291705006653

7. Klump KL, McGue M, Iacono WG. Differential heritability of eating attitudes and behaviors in prepubertal versus pubertal twins. Int J Eat Disord. 2003;33:287-92. doi: 10.1002/eat.10151 
8. Mazzeo SE, Bulik CM. Environmental and genetic risk factors for eating disorders: what the clinician needs to know. Child Adolesc Psychiatr Clin N Am. 2009;18:67-82. doi: http://dx.doi.org/10.1016/j.chc.2008.07.003

9. Klump KL, Bulik CM, Pollice C, Halmi KA, Fichter MM, Berrettini $\mathrm{WH}$, Kaye WH. Temperament and character in women with anorexia nervosa. J Nerv Ment Dis. 2000;188:559-67. doi: https://doi.org/10.1097/00005053-200009000-00001

10. Ruuska J, Kaltiala-Heino R, Koivisto A. Puberty, sexual development and eating disorders in adolescent outpatients. Eur Child Adolesc Psychiatry. 2003;12:214-20.

doi: https://doi.org/10.1007/s00787-003-0340-4

11. Becker AE, Grinspoon SK, Klibanski A, Herzog DB. Eating disorders. N Engl J Med. 1999;340:1092-8.

doi: https://doi.org/10.1056/nejm199904083401407

12. Koff E, Rierdan J. Advanced pubertal development and eating disturbance in early adolescent girls. J Adolesc Health. 1993; 14:433-9. doi: https://doi.org/10.1016/1054-139x(93)90113-4

13. Jurčić Z. Razvojni aspekti anoreksije nervoze. Paediatr Croat. 2004;48:169-77. (in Croatian)

14. Halmi KA, Bellace D, Berthod S, Ghosh S, Berrettini W, Brandt HA, Strober M. An examination of early childhood perfectionism across anorexia nervosa subtypes. Int J Eat Disord. 2012;45:800-7. doi: https://doi.org/10.1002/eat.22019

15. Kaye WH, Bulik CM, Thornton L, Barbarich N, Masters K. Comorbidity of anxiety disorders with anorexia and bulimia nervosa. Am J Psychiatry. 2004;161:2215-21. doi: https://doi.org/10.1176/appi.ajp.161.12.2215

16. Bowlby J. Attachment and Loss: Vol. 1. Attachment. New York: Basic Books; 1982.

17. Main M. Cross-cultural studies of attachment organization: recent studies, changing methodologies, and the concept of conditional strategies. Human Development. 1990;33:48-61. doi: https://doi.org/10.1159/000276502

18. Fraley RC, Niedenthal PM, Marks M, Brumbaugh C, Vicary A. Adult attachment and the perception of emotional expressions: probing the hyperactivating strategies underlying anxious attachment. J Pers. 2006;74:1163-90. doi: https://doi.org/10.1111/j.1467-6494.2006.00406.x

19. Lee A, Hankin BL. Insecure attachment, dysfunctional attitudes, and low self-esteem predicting prospective symptoms of depression and anxiety during adolescence. J Clin Child Adolesc Psychol. 2009;38:219-31.

doi: https://doi.org/10.1080/15374410802698396

20. Schipper M, Petermann F. Relating empathy and emotion regulation: do deficits in empathy trigger emotion dysregulation? Soc Neurosci. 2013;8:101-7.

doi: 10.1080/17470919.2012.761650

21. Keen S. Empathy and the Novel. New York: Oxford University Press; 2007. doi: https://doi.org/10.1093/acprof:oso/9780195 175769.001.0001

22. Kohler W. Gestalt Psychology. New York: Liveright; 1929.
23. Eisenberg N, Miller PA. The relation of empathy to prosocial and related behaviors. Psychol Bull. 1987;101:91-119. doi: https://doi.org/10.1037//0033-2909.101.1.91

24. Oldershaw A, Hambrook D, Tchanturia K, Treasure J, Schmidt U. Emotional theory of mind and emotional awareness in recovered anorexia nervosa patients. Psychosom Med. 2010;72: 73-9. doi: https://doi.org/10.1097/psy.0b013e3181c6c7ca

25. Beadle JN, Paradiso S, Salerno A, McCormick LM. Alexithymia, emotional empathy, and self-regulation in anorexia nervosa. Ann Clin Psychiatry. 2013;25:107-20.

26. Davies H, Schmidt U, Stahl D, Tchanturia K. Evoked emotional expression and experience in anorexia nervosa. Int J Eat Disord. 2011;44:531-9. doi: https://doi.org/10.1002/eat.20852

27. Davies H, Schmidt U, Tchanturia K. Emotional facial expression in women recovered from anorexia nervosa. BMC Psychiatry. 2013;13:291. doi: 10.1186/1471-244X-13-291

28. Gross JJ, Levenson RW. Hiding feelings: the acute effects of inhibiting negative and positive emotion. J Abnorm Psychol. 1997;106:95-103.

doi: https://doi.org/10.1037//0021-843x.106.1.95

29. Hambrook D, Tchanturia K, Schmidt U, Russell T, Treasure J. Empathy, systemizing, and autistic traits in anorexia nervosa: a pilot study. Br J Clin Psychol. 2008;47:335-9.

doi: https://doi.org/10.1348/014466507x272475

30. Evans EH, Tovee MJ, Boothroyd LG, Drewett RF. Body dissatisfaction and disordered eating attitudes in 7- to 11-year-old girls: testing a sociocultural model. Body Image. 2012;10(1): 8-15. doi: /10.1016/j.bodyim.2012.10.001

31. Stice E. Risk and maintenance factors for eating pathology: a meta-analytic review. Psychol Bull. 2002;128:825-48. doi: https://doi.org/10.1037//0033-2909.128.5.825

32. Pokrajac-Bulian A, Mohorić T, Đurović D. Disturbed eating habits, body dissatisfaction, and frequency of dieting behavior in Croatian high school population. Psychol Topics. 2007;16: 27-46.

33. American Psychiatric Association. Diagnostic and Statistical Manual of Mental Disorders, $4^{\text {th }}$ edn. Washington DC: American Psychiatric Association; 1994. doi: https://doi.org/10.1007/springerreference_179660

34. Society for Adolescent Medicine. Guidelines for adolescent health research. J Adolesc Health. 2003;33:396-409. doi: 10.1016/j.jadohealth.2003.06.009

35. Bravender T, Bryant-Waugh R, Herzog D, Katzman D, Kreipe RD, Lask B, Le Grange D, Lock J, Loeb K, Madden S, Nicholls D, O'Toole J, Pinhas L, Rome E, Sokol-Burger M, Wallen $\mathrm{U}$, Zucker N. Classification of child and adolescent eating disturbances. Workgroup for Classification of Eating Disorders in Children and Adolescents (WCEDCA). Int J Eat Disord. 2007;40:117-22. doi: https://doi.org/10.1002/eat.20458

36. Rholes WS, Simpson JA. Adult Attachment: Theory, Research, and Clinical Implications. New York: Guilford; 2004. doi: https://doi.org/10.1086/449322 
37. Sibley CG, Fischer R, Liu JH. Reliability and validity of the revised experiences in close relationships (ECR-R) self-report measure of adult romantic attachment. Pers Soc Psychol Bull. 2005;31:1524-36. doi: 10.1177/0146167205276865.

38. Fraley RC, Waller NG, Brennan KA. An item-response theory analysis of self-report measures of adult attachment. J Pers Soc Psychol. 2000;78:350-65.

doi: https://doi.org/10.1037//0022-3514.78.2.350

39. Jolliffe D, Farrington DP. Development and validation of the Basic Empathy Scale. J Adolesc. 2006;29:589-611. doi: 10.1016/j.adolescence.2005.08.010

40. Thompson JK, van den Berg P, Roehrig M, Guarda AS, Heinberg LJ. The Sociocultural Attitudes Towards Appearance scale-3 (SATAQ-3): development and validation. Int J Eat Disord. 2004;35:293-304. doi: 10.1002/eat.10257

41. Stefanile C, Matera C, Nerini A, Pisani E. Validation of an Italian version of the Sociocultural Attitudes Towards Appearance Questionnaire-3 (SATAQ-3) on adolescent girls. Body Image. 2011;8:432-36. doi: 10.1016/j.bodyim.2011.06.001

42. Goodman R. The strengths and difficulties questionnaire: a research note. J Child Psychol Psychiatry. 1997;38:581-6. doi: 10.1111/j.1469-7610.1997.tb01545.x

43. Goodman A, Goodman R. Strength and difficulties questionnaire as a dimensional measure of a child mental health. J Am Acad Child Adolesc Psychiatry. 2009;48:400-3. doi : 10.1097/CHI.0b013e3181985068

44. Dunlap WP, Cortina JM, Vaslow JB, Burke MJ. Meta-analysis of experiments with matched groups or repeated measures designs. Psychol Methods. 1996;1:170-7.

doi: https://doi.org/10.1037//1082-989x.1.2.170

45. Newman DL, Moffitt TE, Caspi A, Magdol L, Silva PA, Stanton WR. Psychiatric disorder in a birth cohort of young adults: prevalence, comorbidity, clinical significance, and new case incidents from ages 11 to 21. J Consult Clin Psychol. 1996; 64:552-62. doi: https://doi.org/10.1037/0022-006x.64.3.552

46. Wilson GT, Heffernan K, Black CMD. Eating disorders. In: Mash EJ, Barkley RA, editors. Child Psychopathology. New York: Guilford Press; 1996. doi: http://dx.doi.org/10.1016/ S0272-7358(97)00034-2

47. Shisslak C, Crago M. Primary prevention of eating disorders. J Consult Clin Psychol. 1987;55:660-7. doi: https://doi.org/10.1037//0022-006x.55.5.660

48. Mayhew R, Edelmann RJ. Self-esteem, irrational beliefs and coping strategies in relation to eating problems in a non-clinical population. Pers Individ Diff. 1989;10:581-4. doi: http:// dx.doi.org/10.1016/0191-8869(89)90042-1

49. Grant CL, Fedor IG. Adolescent attitudes toward body image and anorexic behaviors. Adolescence. 1986;21:269-81.

50. Halmi KA, Eckert E, Marchi PA, Sampugnaro V, Apple R, Cohen J. Comorbidity of psychiatric diagnoses in anorexia nervosa. Arch Gen Psychiatry. 1991;48:712-8. doi: 10.1001/archpsyc.1991.01810320036006
51. Thompson JK, Coovet MD, Richards KJ, Johnson S, Cattarin J. Development of body image, eating disturbance, and general psychological functioning in female adolescents: covariance structure modeling and longitudinal investigations. Int J Eat Disord. 1995;18:221-36. doi: 10.1002/1098-108X(199511) 18:3<221::AID-EAT2260180304>3.0.CO;2-D

52. Leon GR, Fulkerson JA, Perry CL, Early-Zald MB. Prospective analysis of personality and behavioral vulnerabilities and gender influences in later development of disordered eating. J Abnorm Psychol. 1995;104:140-9. doi: https://doi.org/10.1037//0021-843x.104.1.140

53. Rosen J, Gross J, Vara L. Psychological adjustment of adolescents attempting to lose or gain weight.J Consult Clin Psychol. 1987;55:742-7.

doi: https://doi.org/10.1037//0022-006x.55.5.742

54. Fonagy P, Leigh T, Steele M, Kennedy R, Mattoon G, Target $\mathrm{M}$, Gerber A. The relation of attachment status, psychiatric classification, and response to psychotherapy. J Consult Clin Psychol. 1996;64:22-31.

doi: https://doi.org/10.1037//0022-006x.64.1.22

55. Candelori C, Ciocca A. Attachment and eating disorders. In: Bria P, Ciocca A, de Risio S, editors. Psychotherapeutic Issues in Eating Disorders: Models, Methods and Results. Rome: Societa Editrice Universo; 1998. doi: 10.1002/(SICI)10990968(199905)7:2<149::AID-ERV291>3.0.CO;2-0

56. Chassler L. (1997). Understanding anorexia nervosa and bulimia nervosa from an attachment perspective. Clin Soc Work J. 1997;25:407-23.

57. Harrison A, Sullivan S, Tchantura K, Treasure J. Emotional functioning in eating disorders: attentional bias, emotion recognition and emotion regulation. Psychol Med. 2010;40: 1887-97. doi: https://doi.org/10.1017/S0033291710000036

58. Garner DM, Garfinkel PE. Socio-cultural factors in the development of anorexia nervosa. Psychol Med. 1980;10:647-56. doi: https://doi.org/10.1017/S0033291700054945

59. Wiseman C, Gray J, Mosimann J, Ahrens A. Cultural expectations of thinness in women: an update. Int J Eat Disord. 1992; 11:85-9. doi: 10.1002/1098-108X(199201)11:1<85::AIDEAT2260110112>3.0.CO;2-T

60. Harrison K, Cantor J. The relationship between media consumption and eating disorders. J Commun. 1997;47:40-67. doi: 10.1111/j.1460-2466.1997.tb02692.x

61. Levine MP, Smolak L. Media as a context for the development of disordered eating. In: Smolak L, Levine MP, Striegel-Moore R, editors. Developmental Psychopathology of Eating Disorders: Implications for Research, Prevention and Treatment. Hillsdale, NJ, USA: Erlbaum; 1996: p. 235-57. doi: https://doi.org/10.4324/9780203763506

62. Stice E, Whitenton K. Risk factors for body dissatisfaction in adolescent girls: a longitudinal investigation. Dev Psychol. 2002;38:669-78.

doi: https://doi.org/10.1037//0012-1649.38.5.669 
63. Thompson JK, Stice E. Thin-ideal internalization: mounting evidence for a new risk factor for body-image disturbance and eating pathology. Curr Dir Psychol Sci. 2001;10:181-3. doi: https://doi.org/10.1111/1467-8721.00144

64. Heinberg LJ, Guarda AS, Haug NA. (2001). Sociocultural attitudes predict partial hospitalization weight gain. [presented at the Annual Meeting of the Eating Disorder Research Society, Albuquerque, NM, 2001]. (poster)

65. Stice E, Hoffman E. Eating disorder prevention programs. In: Thompson JK, editor. Handbook of Eating Disorders and Obesity. New York: Wiley; 2004: p. 33-57.
66. Garner DM, Garfinkel PE, Schwartz D, Thompson M. Cultural expectations of thinness in women. Psychol Rep. 1980; 47:483-91. doi: https://doi.org/10.2466/pr0.1980.47.2.483

67. Grabe S, Ward LM, Hyde JS. The role of the media in body image concerns among women: a meta-analysis of experimental and correlational studies. Psychol Bull. 2008;134:460-76. doi: https://doi.org/10.1037/0033-2909.134.3.460

68. Stice E, Shaw HE. Role of body dissatisfaction in the onset and maintenance of eating pathology: a synthesis of research findings. J Psychosom Res. 2002;53:985-93. doi: https://doi.org/10.1016/s0022-3999(02)00488-9

Sažetak

\title{
PREDIKTORI RIZIKA ZA RAZVOJ POREMEĆAJA JEDENJA U ADOLESCENTICA S ANOREKSIJOM NERVOZOM
}

\author{
M. Batista, L. Žigić Antić, O. Žaja, T. Jakovina i I. Begovac
}

Cilj ovoga istraživanja bio je ispitati povezanost između rizika za razvoj poremećaja u jedenju (ED), psihološke prilagodbe, empatije, privrženosti i internalizacije mršavosti među adolescentima s anoreksijom nervozom (AN) u odnosu na zdravu kontrolnu skupinu (HC). Upitnik općih podataka, Upitnik o poremećaju jedenja-3 (EDI-3), Upitnik sociokulturnih stavova prema izgledu-3 (SATAQ-3), Revidirani upitnik o iskustvima u bliskim odnosima (ECR-R) i Upitnik o empatiji (BES) ispunilo je 35 adolescentica s dijagnosticiranim poremećajem u jedenju (anoreksija nervoza) i 35 zdravih adolescentica koje su činile kontrolnu skupinu. Rizik za razvoj poremećaja u jedenju se pronašao najvećim u adolescentica s anoreksijom nervozom koje su imale značajne teškoće u općoj psihološkoj prilagodbi, zatim u zdravih adolescentica kod kojih se potvrdila značajna internalizacija ideala mršavosti. U djevojaka s utvrđenom dijagnozom anoreksije nervoze, stil privrženosti i internalizacija ideala mršavosti se nisu pokazali značajnim prediktorom, u kombinaciji s faktorom opće psihološke neprilagodbe, za rizik za razvoj poremećaja u jedenju. Rezultati podupiru konstrukt poremećaja u jedenju koji naglašava ulogu opće psihološke prilagodbe u razvoju poremećaja u jedenju.

Ključne riječi: Anoreksija, nervoza; Adolescent; Psihološka prilagodba; Poreméaji hranjenja; Empatija; Ankete i upitnici; Hrvatska 